\title{
Cross Layer- Performance Enhancement Architecture (CL-PEA) for MANET
}

\author{
Mehajabeen Fatima ${ }^{1}$, Roopam Gupta ${ }^{2}$, T K Bandhopadhyay ${ }^{3}$ \\ ${ }^{12}$ RGPV, Bhopal, India \\ ${ }^{3}$ BIST, Bhopal, India \\ E-mail: 'mehajabeen.fatima@gmail.com,2roopam_1710@yahoo.co.in, 3ushar_bando1@gmail.com
}

\begin{abstract}
Internet is based on TCP/IP but TCP/IP architecture is not sufficient to cope with the dynamics of MANET. Number of architectures are already available in literature but cross layer architecture is most popular one. To enhance performance of protocols a Cross Layer- Performance Enhancement Architecture (CL-PEA) is proposed. In this architecture one hardware layer is added and all layers can exchange their parameters. CLPEA enhances the protocol performances by taking decisions on the basis of information available on layers.
\end{abstract}

Keywords: TCP/IP, MANET, CL-PEA, Cross Layer, Protocol.

\section{INTRODUCTION}

MANET is a special type of wireless network in which a collection of mobile network interfaces may form a temporary network without the aid of any established infrastructure or centralized administration. Ad Hoc wireless network has applications in emergency search-and-rescue operations, decision making in the battlefield, data acquisition operations in hostile terrain, etc. It is featured by dynamic topology, multi-hop communication, limited resources (bandwidth, CPU, battery, etc.) and limited security [1]. An accelerating energy crisis in the oil and gas industry leads the development and investment in MANET technologies. Actually, the availability of crude oil in the remote area of seas, it is very difficult to implement infrastructure oriented network for communication. Here it is difficult to provide infrastructure in such places. And deployment of such network is very costly. Sometimes the working staff faces disastrous situations in such remote areas and it is very difficult for them to communicate with each other without any infrastructure, hence required an infrastructure less network (MANET) [2]. MANET was designed to work in the situations such that whenever certain number of nodes come together in transmission area of each other, the nodes should be able to communicate. The formed network is temporary, so nodes are equipped with low power and computing with routing capabilities. Because, in MANET, topology frequently changes, and nodes have got limited power so its routing is challenged by these factors. So conventional routing protocols cannot be used here. Nodes in an ad hoc environment face major challenges of mobility, traffic, scalability, power consumption etc. The mobility in an ad hoc network can be featured by the speed of nodes in the systems and the duration of the pause time during which nodes become stationary. One of the most widely used mobility models is the random waypoint model first proposed in [3]. In this model, nodes choose destination, and move towards it at a random speed uniformly chosen from (0, Vmax), where Vmax is the maximal speed of the node. If a node pauses then it pauses for a constant time and then it start moving with specified speed [4]. The average speed of nodes in the system determines the rate at which route breaks and consequently the control traffic consumed by the route repairing in on-demand protocols. The increased routing control traffic badly affects the packet delivery ratio, power consumption, delay, throughput etc. As with increase in traffic, chances of route breakage increases. The routing protocols of such networks 
must be able to perform efficiently and effectively, adapting to any changes. The performance of network is also badly affected with the increase in size of network. So scalability is a major concern. The power consumption increases with increase in traffic, scalability, mobility. To cope with these dynamics of MANET different architecture is required like cross layer approach.

\section{CROSS LAYER APPROACH}

The internet is based on TCP/IP architecture and it is a worldwide success. TCP/IP was originally designed for wired links, characterized by high bandwidth, low delay, and low probability of packet loss (high reliability), static routing and no mobility [5]. But in the wireless links, performance and resources are limited by the time-varying channel performance, the scarce availability of transmission spectrum, the employed modulation type and the limited transmission power $[6,7,8]$. TCP/IP is a hierarchical model in which only adjacent layers communicate with each other. But a strict layered design is insufficient to cope with the dynamics of ad hoc networks. So instead of using $\mathrm{TCP} / \mathrm{IP}$, cross layer architecture can be a more promising architecture for ad hoc networks.

Cross-layer design breaks the traditional network design, where each layer of the protocol stack operates independently and exchanges information with adjacent layers only. In the cross-layer approach information is exchanged among all layers without following any hierarchy of protocol stack [9] and performance is optimized by adapting each layer. Cross-layering breaks the boundaries between information abstractions to improve performance of the network. The careful exploitation of cross-layer protocol interactions can lead to more efficient performance of the protocol stack [10].

Physical layer, MAC layer and Network layer together contend for the network resource in a wireless network. The transmission power and data rate decide at the physical layer affects MAC and routing decisions. Scheduling and allocating the wireless channel is done at the MAC layer, which will determine the available bandwidth of the transmitter and the packet delay. The available bandwidth and delay in the transmission of packets also affect the decision at the routing layer to select the route. The routing protocol in the network layer chooses the routes to transmit data packets. The routing decision will change the contention level at the MAC layer and accordingly the physical layer parameters [11]. Thus all layers depend on each other and any change on any layer will propagate to all layers. Thus cross layer design can be a promising alternative but unbridled design may lead to negative consequences. CLD is to combine the resources available in the different communities, and create a network which can be highly adaptive and QoS-efficient by sharing information between different processes or modules in the system.

\section{DIFFERENT ARCHITECTURES}

There are many cross-layer design proposals in the literature. A survey of different cross layer architectures are given in Table 1.

A common database that can be accessed by all layers is discussed in [6]. The common database is like a new layer, providing the service of storage/retrieval of information to all the layers. According to this architecture, all parameters of layers are stored in database layer and all of the layers can communicate at any time with any layer. But all parameters of different layers need not to store in database layer. If all parameters stores then it requires large buffer size. Instead of doing this, an additional hardware layer can be introduced which can store parameters of hardware, operating system etc, not the parameters of layers which are already available at layers. So a cross layer architecture is proposed.

Table 1: Different Architectures

\begin{tabular}{|l|l|l|l|l|}
\hline $\begin{array}{l}\text { Author } \\
\text { Name }\end{array}$ & Issues dicussed & Basic principle & Pros & Cons \\
\hline $\begin{array}{l}\text { Vineet } \\
\text { shrivastava, } \\
\begin{array}{l}\text { Mehul } \\
\text { motani[10] }\end{array}\end{array}$ & $\begin{array}{l}\text { Survey of } \\
\text { different } \\
\text { proposed cross } \\
\text { layer design in } \\
\text { literature is } \\
\text { given }\end{array}$ & $\begin{array}{l}\text { How TCP/IP architecture } \\
\text { violation can be possible. }\end{array}$ & $\begin{array}{l}\text { Very good } \\
\text { survey is } \\
\text { provided }\end{array}$ & $\begin{array}{l}\text { Only survey is } \\
\text { given, } \\
\text { implementation } \\
\text { is not discussed }\end{array}$ \\
\end{tabular}


Mehajabeen Fatima et al. / International Journal of Computer Networks and Communications Security, 1 (2), JULY 2013

\begin{tabular}{|c|c|c|c|c|}
\hline $\begin{array}{l}\text { Vijay } \quad \mathrm{T} \text {. } \\
\text { Raisingahani } \\
\text { and Sridhar } \\
\text { Iyer[12] }\end{array}$ & $\begin{array}{l}\text { An ÉCLAIR } \\
\text { local-view- } \\
\text { based cross } \\
\text { layer } \\
\text { architecture is } \\
\text { proposed }\end{array}$ & $\begin{array}{l}\text { With legacy protocol stack it } \\
\text { consists of two main } \\
\text { components: an Optimizing } \\
\text { Sub-System, the cross layer } \\
\text { engine which contains many } \\
\text { Protocol Optimizers, } \\
\text { which are the "intelligent" } \\
\text { components of it, and } \\
\text { TuningLayers. Different } \\
\text { tuning layers are included in } \\
\text { TCP/IP architecture. These } \\
\text { tuning layers are new } \\
\text { interfaces. These new } \\
\text { interfaces are included at } \\
\text { different layers }\end{array}$ & $\begin{array}{l}\text { Tuning } \\
\text { Layers. } \\
\text { provide the } \\
\text { necessaryAPI } \\
\mathrm{s} \text { to the } \\
\text { protocol } \\
\text { optimizers for } \\
\text { interacting } \\
\text { with various } \\
\text { layers and } \\
\text { manipulating } \\
\text { the protocol } \\
\text { data } \\
\text { structures. }\end{array}$ & $\begin{array}{l}\text { This architecture } \\
\text { requires new } \\
\text { interfaces. }\end{array}$ \\
\hline $\begin{array}{l}\text { Rolf Winter } \\
\text { et.al.[11] }\end{array}$ & $\begin{array}{l}\text { proposed a } \\
\text { cross layer } \\
\text { architecture } \\
\text { called cross talk } \\
\text { is based on data } \\
\text { dissemination }\end{array}$ & $\begin{array}{l}\text { They propose a data } \\
\text { dissemination process } \\
\text { consists of two data } \\
\text { management entities. One is } \\
\text { responsible for the } \\
\text { organization of locally } \\
\text { available information and the } \\
\text { other entity establishes a } \\
\text { network-wide or global view } \\
\text { of the same type of } \\
\text { information collected in the } \\
\text { local view. }\end{array}$ & $\begin{array}{l}\text { In this } \\
\text { architecture } \\
\text { only data } \\
\text { packets are } \\
\text { transmitted } \\
\text { with different } \\
\text { values } \\
\text { piggybacked } \\
\text { and control } \\
\text { packets are } \\
\text { not } \\
\text { transmitted }\end{array}$ & $\begin{array}{l}\text { Because of } \\
\text { piggybacking } \\
\text { packet size } \\
\text { increases and it } \\
\text { is obvious that } \\
\text { large packet } \\
\text { takes more time } \\
\text { to transmit and } \\
\text { receive, } \\
\text { consumes large } \\
\text { bandwidth }\end{array}$ \\
\hline $\begin{array}{l}\text { Vikas } \\
\text { Kawadia and } \\
\text { P.R.Kumar[1 } \\
\text { 3] }\end{array}$ & $\begin{array}{lr}\text { Different } & \\
\text { principles } & \text { of } \\
\text { cross } & \text { layer } \\
\text { design } & \text { are } \\
\text { discussed. } & \end{array}$ & $\begin{array}{l}\text { Principles of cross layer } \\
\text { designs are given like } \\
\text { Interactions and law of } \\
\text { unintended consequences, } \\
\text { dependency graph, timescale } \\
\text { separation and stability, chaos } \\
\text { of unbridled cross layer } \\
\text { design are given }\end{array}$ & $\begin{array}{l}\text { Some } \\
\text { examples are } \\
\text { shown. }\end{array}$ & $\begin{array}{l}\text { improvements } \\
\text { are not given }\end{array}$ \\
\hline $\begin{array}{l}\text { Enrico } \\
\text { Biermann, } \\
\text { Kathrin } \\
\text { Hoffman and } \\
\text { Julie Pedberg }\end{array}$ & $\begin{array}{l}\text { Layered } \\
\text { architecture is } \\
\text { proposed }\end{array}$ & $\begin{array}{l}\text { A new type of hierarchical } \\
\text { model is proposed. All layers } \\
\text { are different from TCP/IP. }\end{array}$ & $\begin{array}{lr}\text { Functions } & \text { of } \\
\text { all layers is } \\
\text { only } & \text { for } \\
\text { MANET } & \end{array}$ & $\begin{array}{l}\text { This architecture } \\
\text { is made in } \\
\text { consideration of } \\
\text { mobile nodes. It } \\
\text { can't be used for } \\
\text { stationary nodes. }\end{array}$ \\
\hline $\begin{array}{l}\text { Marco Conti, } \\
\text { Gaia Maselli, } \\
\text { Giovanni Turi } \\
\text { and Silvia } \\
\text { Giordano[14] }\end{array}$ & $\begin{array}{l}\text { Mobileman } \\
\text { architecture is } \\
\text { proposed }\end{array}$ & $\begin{array}{l}\text { This architecture works on } \\
\text { energy management, security } \\
\text { and cooperation. A network } \\
\text { status is provided which can } \\
\text { communicate with all layers } \\
\text { and all layers can } \\
\text { communicate with network } \\
\text { status. Network status is like } \\
\text { repository. }\end{array}$ & $\begin{array}{l}\text { Whenever a } \\
\text { protocol in } \\
\text { the stack } \\
\text { collects } \\
\text { information, } \\
\text { it will publish } \\
\text { this to the } \\
\text { repository } \\
\text { and thus }\end{array}$ & $\begin{array}{l}\text { MobileMan } \\
\text { reference } \\
\text { architecture is } \\
\text { just a proposal so } \\
\text { far, no per- } \\
\text { formance } \\
\text { analysis exists to } \\
\text { back up their } \\
\text { claims. }\end{array}$ \\
\hline
\end{tabular}




\begin{tabular}{|c|c|c|c|c|}
\hline & & & $\begin{array}{l}\text { making it } \\
\text { available for } \\
\text { every other } \\
\text { protocol. }\end{array}$ & \\
\hline $\begin{array}{l}\text { Frank Aune - } \\
\text { fa une[15] }\end{array}$ & $\begin{array}{l}\text { A survey is } \\
\text { given on } \\
\text { different cross } \\
\text { layer proposals }\end{array}$ & $\begin{array}{ll}\text { LayerTriggers, Event } & \text { Helix', } \\
\text { MobileMan cross layer } \\
\text { proposals are discussed }\end{array}$ & $\begin{array}{lr}\text { Very good } \\
\text { survey is } \\
\text { provided by } \\
\text { this paper }\end{array}$ & $\begin{array}{l}\text { Implementation } \\
\text { is not given }\end{array}$ \\
\hline $\begin{array}{l}\text { Daniel } \\
\text { G.Sachs et } \\
\text { al[16] }\end{array}$ & $\begin{array}{l}\text { GRACE } \\
\text { (Global } \\
\text { Resource } \\
\text { Adaptation } \\
\text { through Co- } \\
\text { opEration) } \\
\text { system) }\end{array}$ & $\begin{array}{l}\text { All system components } \\
\text { (hardware, network, and } \\
\text { operating and applications are } \\
\text { allowed to be adaptive). }\end{array}$ & $\begin{array}{l}\text { These } \\
\text { adaptive } \\
\text { entities co- } \\
\text { operate with } \\
\text { each } \\
\text { other to } \\
\text { achieve a } \\
\text { system-wide } \\
\text { optimal } \\
\text { configuration } \\
\end{array}$ & $\begin{array}{l}\text { its cross-layer } \\
\text { approach } \\
\text { includes no } \\
\text { explicit } \\
\text { consideration of } \\
\text { cross layering } \\
\text { within the } \\
\text { networking or } \\
\text { layers protocol stack. } \\
\text { prot }\end{array}$ \\
\hline $\begin{array}{l}\text { Dzmitry } \\
\text { Kliazovich } \\
\text { and Fabrizio } \\
\text { Granelli [17] }\end{array}$ & $\begin{array}{l}\text { WIDENS } \\
\text { (Wireless } \\
\text { deployable } \\
\text { Network } \\
\text { System) cross } \\
\text { layer design has } \\
\text { been proposed }\end{array}$ & $\begin{array}{lr}\text { It acquired } & \text { the } \\
\text { interoperability, cross } \\
\text { layering and re- } \\
\text { configurability at the same } \\
\text { time. }\end{array}$ & $\begin{array}{l}\text { This cross } \\
\text { layer } \\
\text { architecture } \\
\text { seems a } \\
\text { promising } \\
\text { one where } \\
\text { protocol } \\
\text { optimization } \\
\text { is based on } \\
\text { the local state } \\
\text { information }\end{array}$ & $\begin{array}{l}\text { Real } \\
\text { measurement of } \\
\text { efficiency in } \\
\text { terms } \\
\text { performance } \\
\text { parameter is not } \\
\text { given }\end{array}$ \\
\hline $\begin{array}{l}\text { Vineet } \\
\text { shrivastava, } \\
\text { Mehul } \\
\text { motani[10] }\end{array}$ & $\begin{array}{l}\text { A common } \\
\text { database that } \\
\text { can be accessed } \\
\text { by all layers is } \\
\text { discussed }\end{array}$ & $\begin{array}{l}\text { All layers are supposed to } \\
\text { store their parameters in } \\
\text { common database layer }\end{array}$ & $\begin{array}{l}\text { Availability } \\
\text { of data in } \\
\text { common } \\
\text { database } \\
\text { which will be } \\
\text { accessed by } \\
\text { all layers and } \\
\text { can utilize } \\
\text { information } \\
\text { easily. }\end{array}$ & $\begin{array}{lr}\text { It requires large } \\
\text { buffer size. No } \\
\text { need of keeping } \\
\text { all } & \text { layer } \\
\text { parameters } & \text { in } \\
\text { separate } & \\
\text { database. }\end{array}$ \\
\hline
\end{tabular}

\section{PROPOSED CROSS LAYER- PERFORMANCE ENHANCEMENT ARCHITECTURE(CL-PEA)}

AIM:

1. New architecture should be compatible with traditional architecture. New architecture can be used as cross layer architecture otherwise act as traditional architecture when it is required.
2. Extra interfaces should not required.

3. Packet sizes should not be increased.

4. Buffer size should not be increased.

5. It is not enough simply sharing the resources among the different users, it should be done efficiently and fairly.

Simultaneous optimization of all layers using cross layer design is very difficult. Unbridled design of cross layer may lead to spaghetti design 
[13]. So Cross Layer-Performance Enhance Architecture (CL-PEA) is proposed. In this architecture it is proposed that instead of the database layer, a system hardware layer should add in the traditional protocol stack. This hardware layer can have parameters like speed of a node, battery status, operating system parameter etc. It does not have parameters of other layers as already available at different layers. The hardware layer stores those parameters which are not parameter of any four layers. The parameters of all layers can be called at any other layer and decisions can be taken accordingly e.g. A routing protocol at network layer can use the data available at different layers and decision can be taken on the basis of this. Vertical coupled layers are sufficient to enhance the protocol performance. All the layers can communicate or exchange their information vertically with each other and can take decision accordingly as illustrated in Fig.1. Large buffer size is not required as required in [10], new interfaces are not required as used in [12] for this architecture. Here simply all layers can exchange their parameters to take effective decision. This architecture is same as TCP/IP, the difference is that the all layers can exchange their parameters to take a decision and one more layer is added to TCP/IP protocol stack named Hardware layer. CLPEA is very simple architecture and it is not complex. Only one layer is introduced and all layers can exchange their parameters for taking decision by any layer protocol. With this architecture performance of network can be enhanced.

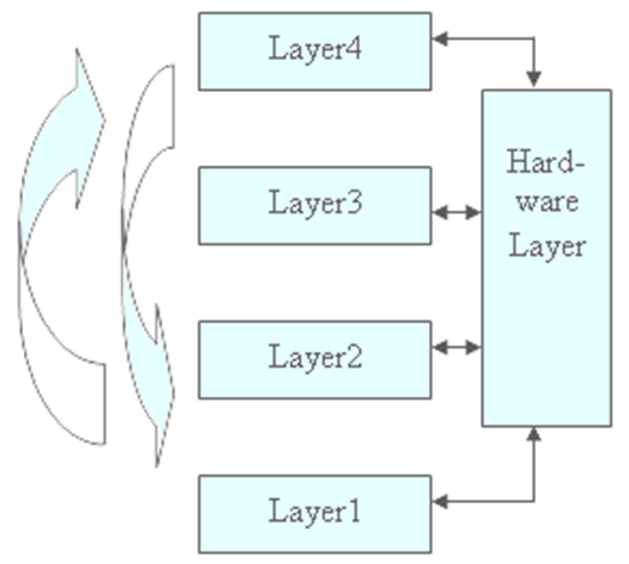

Fig. 1. Cross Layer Performance Enhancement Architecture (CL-PEA)

The aim of cross-layer design is to preserve the functions of a layered architecture and allow performance improvement and adaptability [10, 13].

\section{CONCLUSION}

QoS in wireless ad hoc networks has become a crucial issue due to the proliferation of internet applications, services, emergence and deployment of wireless ad hoc networks. To cope with dynamics of adhoc network, a cross-layer architecture CL_PEA is proposed for QoS. The novel feature of this is the ability to enhance the performance of layer protocols. This architecture is used to reduce power consumption, route breakage, and delay and to improve QoS parameters. In the future we plan several improvements to this architecture.

\section{REFERENCES}

[1] Energy Issues and Energy aware Routing in Wireless Ad-hoc Networks. Rango, Marco Fotino and Floriano De. s.l.: International Journal of Communication System, Mobile Ad-Hoc Networks: Protocol Design, pp. 281296. 2008.

[2] Energy Efficient Routing Protocol Avoiding Route Breaks based on DSR, Ashish Kumar, M. Q. Rafiq, Kamal Bansal International Journal of Computer Applications (0975 8887), Volume 44- No.4, April 2012.

[3] Dynamic Source Routing in AdHoc Wireless Networks, D.B. Johnson, D.A. Maltz, Kluwer Academic, 1996

[4] ZAHEDI, KHALID, et al. "Enhancing the Performance of DSR Routing Protocol Using Link Breakage Prediction in Vehicular Ad Hoc Network" International Journal of Computer Networks and Communications Security 1.1 (2013).

[5] Efficient routing for wireless mesh networks using a backup path. Amir Esmailpour, Nidal Nasser and Jehad Al. May 2012.

[6] Integrating machine learning in ad hoc routing: A wireless adaptive routing protocol. Brian Russel, Michael L. Littman and Wade Trappe. 2011.

[7] Energy-Efficient Network Selection with Mobility Pattern Awareness in an Integrated WiMAX and WiFi Network. Wen-Hsin Yang, You Chiun Wang, Yu-Chee Tseng and Bao- 
Shuh P. Lin. International journal of communication system, 2000.

[8] Cross-layer error recovery in wireless access networks: The ARQ proxy approach Dzmitry Kliazovich, Simone Redana, Fabrizio Granelli. International Journal of Communication System, 2011.

[9] Survey on Mobile Ad Hoc Network Routing Protocols and Cross-Layer Design. S.I. : Liang Qin and Thomas Kunz, Carleton University, Systems and Computer Engineering, Technical Report SCE-04-14, August 2004

[10] Cross-Layer Design: A Survey and the Road Ahead. Vineet Srivastava, Mehul Motani. s.1.: IEEE Communications Magazine, December 2005.

[11]CrossTalk: Cross-Layer Decision Support Based on Global Knowledge. Rolf Winter, Jochen H. Schiller, Navid Nikaein and Christian Bonnet: IEEE Communications Magazine, January 2006.

[12]ECLAIR: AnEfficient Cross Layer Architecture for Wireless Protocol Stacks., V. T. Raisinghani and Iyer. Sridhar: WWC, 2004.

[13] A cautionaryperspective on cross-layer design. Vikas kawadia, p. R. Kumar. IEEE Wireless Communications, February 2005.

[14]Cross layering in mobile Ad Hoc Network Design. Marco Conti, Gaia Maselli, Giovanni Turi, SylviaGiordano. s.l.: IEEE Computer Society, February 2004, pp. pages 48-51.

[15] Cross-Layer Design $T$ utorial. faune, Frank Aune -. s.l.: Published under Creative Commons License, Nov, 2011.

[16] GRACE: A Hierarchical Adaptation Framework for Saving Energy. al, Daniel G.Sachs et. ACEED 2005.

[17] A Cross-layer Scheme for TCP Performance Improvement in Wireless LANs. Granelli, Dzmitry Kliazovich and Fabrizio. s.l.: IEEE Communications Society, Globecom 2004, pp. 841-844. 